\author{
A.S. Magauova iD , Zh.T. Makhambetova \\ Al-Faraby Kazakh National University, Kazakhstan, Almaty, \\ e-mail:magauova@mail.ru, e-mail:mzhamilya@mail.ru
}

\title{
THE READINESS OF FUTURE SOCIAL PEDAGOGUES TO WORK IN INCLUSIVE EDUCATION: RESULTS OF A DIAGNOSTIC RESEARCH
}

The results of a diagnostic research on the readiness of bachelor students of the specialty "Social pedagogy and self-cognition" for practical work in an inclusive education are presented in the article. The research was attended by respondents-students of the third and fourth years of the specialty "Social pedagogy and self-cognition" of the department of pedagogy and educational management of Al-Farabi Kazakh National University (Almaty, Republic of Kazakhstan).

The authors analyzed the difficulties encountered by students during pedagogical practice with a contingent of children with special educational needs; what methods are most often used with students with disabilities and give the most tangible results in correcting children of this category; what qualities should a social pedagogue have who works in an inclusive education. In the course of analyzing the results of the research, the researchers found out about the predisposition of bachelor students of the specialty "Social pedagogy and self-cognition" to practical work in an inclusive education. The set of professionally significant qualities of a social pedagogue that are necessary for effective professional activity in the conditions of inclusion is defined: empathy, resistance to conflicts, stress resistance, tolerance, communication and organizational skills. It is recommended to update the content of training specialists with innovative strategies and models of inclusive education used in international practice.

Key words: content analysis, development of competences, inclusive education, limited health opportunities, qualitative analysis, pedagogical experiment, special educational needs.

\author{
А.С. Магауова, Ж.Т. Махамбетова \\ Әл-Фараби атындағы Қазақ, ұлттық университеті, \\ Қазақстан, Алматы қ., е-mail: magauova@mail.ru mzhamilya@mail.ru
}

\section{Болашақ әлеуметтік педагогтардың инклюзивті білім беруде жұмыс істеуге дайындығы: Аиагностикамық зерттеу нәтижелері}

Мақалада «Әлеуметтік педагогика және өзін-өзі тану» мамандығының бакалавриат студенттерінің инклюзивті білім беру жағдайында тәжірибелік жұмысқа дайындығы туралы диагностикалық зерттеу нәтижелері ұсынылған. Зерттеуге «Әл-Фараби атындағы ҚазҰУ» «Педагогика және білім беру менеАжменті» кафедрасының «Әлеуметтік педагогика және өзін-өзі тану» мамандығының үшінші және төртінші курс студенттері қатысты (А^маты қ., Қазақстан Республикасы). Ерекше білім беру қажеттіліктері бар балалар контингентімен педагогикалық практика кезінде студенттер қандай қиындықтармен бетпе-бет келгенін; денсаулық мүмкіндіктері шектеулі оқушылармен жиі қолданылатын және осы санаттағы балаларды түзетуде айтарлықтай елеулі нәтижелер беретін әдістемелер; инклюзивті білім беру жағдайында жұмыс істейтін әлеуметтік педагог қандай қасиеттерге ие болуы тиіс екендігі та^данды. Зерттеу нәтижелерін та^дау барысында зерттеушілер «әлеуметтік педагогика және өзін-өзі тану» мамандығы бойынша бакалавриат студенттерінің инклюзивті білім беру жағдайында тәжірибелік жұмысқа бейімділігі туралы анықтады. Инклюзия жағдайында тиімді кәсіби қызмет үшін қажетті әлеуметтік педагогтың кәсіби маңызды қасиеттерінің жиынтығы анықталды: эмпатия, қақтығыстарға төзімділік, күйзеліске төзімділік, толеранттылық, коммуникативтік және ұйымдастырушылық дағдылар. Халықаралық тәжірибеде қолданылатын инновациялық стратегиялармен және инклюзивті білім беру үлгілерімен мамандарды даярлау мазмұнын жаңарту ұсыны^ды.

Түйін сөздер: инк^юзивті білім беру, сапалы та^дау, контент-талдау, ерекше білім беру қажеттіліктері, денсаулықтың шектеулі мүмкіндіктері, педагогикалық эксперимент. 


\author{
А.С. Магауова, Ж.Т. Махамбетова \\ Казахский национальный университет имени аль-Фараби, \\ Казахстан, г. Алматы, e-mail: magauova@mail.ru, e-mail: mzhamilya@mail.ru
}

Готовность будущих социамьных педагогов к работе в инкмюзивном образовании:
результаты диагностического исследования

В статье представлены результаты диагностического исследования о готовности студентов бакалавриата специальности "Социальная педагогика и самопознание" к практической работе в условиях инклюзивного образования. В исследовании принимали участие респонденты-студенты третьего и четвертого курсов специальности «Социальная педагогика и самопознание» кафедры педагогики и образовательного менеджмента Казахского национального университета им. альФараби (г. Алматы, Республика Казахстан). Были проанализированы трудности, с которыми столкнулись студенты во время педагогической практики с контингентом Аетей с особыми образовательными потребностями; методики, наиболее часто применяемые с учащимися с ограниченными возможностями зАоровья и дающие наиболее ощутимые результаты в коррекции Аетей данной категории; качества, которыми должен обладать социальный педагог, работающий в условиях инклюзивного образования. В ходе анализа результатов исследования исследователи выяснили опреАрасположенности студентов бакалавриата специальности «Социальная педагогика и самопознание" к практической работе в условиях инклюзивного образования. Определен набор профессионально значимых качеств социального педагога, которые необходимы для эффективной профессиональной деятельности в условиях инклюзии: эмпатия, устойчивость к конфликтам, стрессоустойчивость, толерантность, коммуникативные и организационные навыки. Рекомендовано обновить содержание подготовки специалистов инновационными стратегиями и моделями инкАюзивного образования, используемыми в международной практике.

Кмючевые слова: инклюзивное образование, качественный анализ, контент-анализ, особые образовательные потребности, ограниченные возможности здоровья, педагогический эксперимент, формирование компетенций.

\section{Introduction}

The education system around the world is constantly changing and developing. Specialists in the field of educational Sciences are directly involved in the development of their own skills to be competent and able to solve the problems of the socioeconomic environment in a continuous process of change. Inclusive education is one of the most pressing current issues, as not all children receive an education that allows them to reach their full potential. Inclusion applies to all children, as inclusive education is an education in which all children have access to quality education in an inclusive environment (Mag, 2017) [1].

Individuals with special educational needs need specialists to help them adapt, learn and develop throughout their lives. Due to the ongoing transformations in the education system of the Republic of Kazakhstan, the need for high-quality training and retraining of qualified specialists, in particular social pedagogues, to work in inclusive education is increasing.

The aim of this study is to identify the initial level of readiness of social pedagogues to work in an inclusive education in the higher education system.

The subject of the study is the process of development of readiness of social pedagogues for inclusive education in the higher education system.

Research hypothesis: development of readiness of social pedagogues for inclusive education in the higher education system will be more productive if: transformation of personal and professional experience of the pedagogue is directed to successful realization of his professional activity in the conditions of inclusive education.

The importance of the work: In modern scientific literature there is a new approach to the essence of the social pedagogue. According to researchers, social pedagogy can be described as a place where education and care meet, as a concern for the upbringing of children, as a broad educational approach to social problems, education that occurs in everyday life, and as education in the broadest sense (Petrie, 2006). The category of people with special needs needs those specialists who will contribute to socialization, learning and success in life.

Future social pedagogues require the development of professional competencies necessary for productive activities in an inclusive education. In this regard, we conducted this pilot study.

Research objectives: to find out the initial level of formerdness of professional competences of future social pedagogues for work in the conditions of inclusive education. 


\section{Material and Methods}

\section{General characteristic}

The research was combined (quantitative and qualitative). The study was aimed at obtaining primary information about the readiness of bachelor degree students for practical work in an inclusive education. Our research is based on the methodology of designing a qualitative study developed by Marshall \& Rossman, (2011).)[3]. The survey was conducted in the first semester (October) of the 2018/2019 academic year. We analyzed the difficulties faced by students during pedagogical practice with a contingent of children with special educational needs; what methods are most often used with students with limited health opportunities and giving the most tangible results in the correction of children in this category; what qualities should have a social pedagogue working in an inclusive education.

The study involved 44 respondents-students of the $3^{\text {rd }}$ and $4^{\text {th }}$ year of the specialty "Social pedagogy and self-cognition" of the Kazakh and Russian departments of the Department of pedagogy and educational management of Al-Farabi Kazakh National University. (Almaty, Republic of Kazakhstan). Students, according to their gender: 43 women and 1 man. Students ranged in age from 18 to 21 . The questionnaire was filled in by respondents for $20-30$ minutes. During the survey, the principles of anonymity and voluntariness were observed. The calculation of the survey results was carried out as a percentage.

The study used a questionnaire developed by researchers containing 11 open-ended questions.

The questions of the questionnaire:

What difficulties have you encountered during pedagogical practice with a contingent of children with (SEN) special educational needs?

What techniques do you use to work with this contingent of learners?

What techniques according to the observations of future social pedagogues give the most tangible results in the correction of children with SEN (special educational needs)?

List the qualities that a social pedagogue has working with children with (SEN) special educational needs?

These studies were obtained by answering questions in written form. Later, the respondents' answers were coded. The most frequently repeated semantic units were grouped until the original groups, called subcategories, appeared. In the second stage, subcategories were combined into semantic categories. Qualitative study of the data was processed using quantitative content analysis, when the informative highlighted the essential characteristics of the array. The inductive method was chosen, i.e. from the particular to the general.

\section{Results and Discussion}

After analyzing the answers of students, difficulties in the work of the future social teacher and psychological and pedagogical features of children with special educational needs are defined in 2 categories:. The results are shown in table 1.

In table №1, it can be seen that the difficulties in the work of the future social pedagogue $(85 \%)$ were important. This category consists of 4 subcategories: difficulties in relationships (43.3\%), difficulties in organization of work (5\%), lack of academic and professional training (23.4\%), psychological unpreparedness (13.3\%). Psycho- pedagogical features of children with SEN (11.7\%), where the components of subcategories: the child's disease and pronounced hyperactivity. The remaining 3.3\% had no difficulties during pedagogical practice with the contingent of children with special educational needs.

In the scientific literature the issue of teacher's readiness for activity in the context of inclusive education is considered (Kirillova, 2016).

After analyzing the answers of students, methods are most often used with learners with limited health opportunities (lho) are defined in 4 categories: method, type, direction and forms. The results are shown in table №2. In table №2, it can be seen that the methods used to work with learners with limited health opportunities (LHO) $(62.3 \%)$ show the highest rates compared to the types $(5.9 \%)$, directions $(2.4 \%)$ and forms $(20 \%)$. These methods consist of methods of psychotherapy, method of art therapy, methods of training and education, methods of pedagogical research. The highest rate is given by methods of training and education (38.85\%).

In the scientific literature, art therapy means that this method is "a relatively new method of psychotherapy, which has received active, rapid development in recent years. The term (art therapy) appeared only in the early 1940s (literally: treatment by art), and introduced it into use by the artist Adrian Hill in 1938 when describing his work with tuberculosis patients in sanatoriums. These methods were used in the United States in working with children taken from Nazi camps during World War II. At the beginning of its development, art therapy reflected the psychoanalytic views of Freud and Jung, according to which the final product of the client's artistic activity (whether drawing, sculpture, installation) expresses his unconscious mental processes. In 1960, the 
American art therapy Association was established in America (Осипова, 2004). Currently, the term "art therapy" refers to the use of visual arts (drawing, painting, modeling, plastic, makeup, body art.)»

Table 1 - Difficulties, future social pedagogues have encountered during pedagogical practice with a contingent of children with (SEN) special educational needs

\begin{tabular}{|c|c|c|c|c|c|}
\hline Category & № $(\%)$ & Subcategory & № $(\%)$ & Subcategory components & $\mathrm{N}(\%)$ \\
\hline \multirow{7}{*}{$\begin{array}{l}\text { Difficulties in the work of } \\
\text { the future social pedagogue }\end{array}$} & \multirow{7}{*}{$51(85)$} & \multirow[t]{2}{*}{ Difficulties in relationship } & \multirow[t]{2}{*}{$26(43.3)$} & $\begin{array}{l}\text { Difficulties in } \\
\text { establishment } \\
\text { relationships }\end{array}$ & $17(28.3)$ \\
\hline & & & & Communication Difficulties & $9(15)$ \\
\hline & & \multirow{2}{*}{$\begin{array}{c}\text { Difficulties in organization of } \\
\text { work }\end{array}$} & \multirow{2}{*}{$3(5)$} & $\begin{array}{l}\text { Difficult to work with } \\
\text { hyperactive children }\end{array}$ & $2(3.3)$ \\
\hline & & & & Assessment & $1(1.7)$ \\
\hline & & \multirow{2}{*}{$\begin{array}{l}\text { Lack of academic and } \\
\text { professional training }\end{array}$} & \multirow{2}{*}{$14(23.4)$} & $\begin{array}{l}\text { Difficulties in explaining } \\
\text { educational materials }\end{array}$ & $1(1.7)$ \\
\hline & & & & $\begin{array}{l}\text { Lack of knowledge of working } \\
\text { with children with SEN }\end{array}$ & $13(21.7)$ \\
\hline & & Psychological unpreparedness & $8(13.3)$ & Psychological unpreparedness & $8(13.3)$ \\
\hline \multirow{2}{*}{$\begin{array}{l}\text { Psycho-pedagogical } \\
\text { features of children with } \\
\text { SEN }\end{array}$} & \multirow{2}{*}{$7(11,7)$} & \multirow{2}{*}{$\begin{array}{l}\text { Inclusion of persons with } \\
\text { limited health opportunities }\end{array}$} & \multirow{2}{*}{$7(11,7)$} & Child's disease & $4(6.7)$ \\
\hline & & & & Pronounced hyperactivity & $3(5)$ \\
\hline & & & & Had no difficulties & $2(3.3)$ \\
\hline
\end{tabular}

Fairytale is the most integral method of art therapy, including almost all other areas-drawing and painting, work with mask and makeup, dramatization, music-, biblio-, puppet, dance and motor therapy, etc. (Колошина, 2010).

The conversation requires knowledge of the individual characteristics of the children, the ability to listen and understand the emotional state, which requires the researcher to preliminary study the personal files of learners, health maps, creative works, etc. (Хамитова, 2018).

Researchers Zhumasheva S. A., Panikarskaya M. A., et al. (2019) note that in the Kazakhstani school, game technologies occupy a leading place, since they are used by teachers in their various subjects of innovative inclusive education.

The results obtained by researchers in the study of gaming preferences of children with limited health opportunities, identified through questionnaires and interviews, suggest that this category has a high level of development needs in the game. Children of primary school age prefer in non-game communication to friends and parents, and teenagers-to peers and last of all to parents and teachers (Лахин, 2018). In science, Gestalt therapy is considered as one of the directions of psychotherapy.

The word "Gestalt" in German means completeness. The founder of Gestalt therapy Fritz (Frederick) Salomon Perls believed that in the endless process of achieving completeness and satisfaction of their needs, in the process of forming completions, or gestalts is one of the fundamental laws of nature, supporting the integrity of living organisms. Fritz Perls (1893 - 1970) - founder of Gestalt therapy and master of practical use of Gestalt, set a goal to help people become more aware of themselves and their bodies. Like many other creators of new psychotherapeutic schools, in his development as a psychotherapist Perls was greatly influenced by Freud, from whom he studied psychoanalysis.

It should be noted that the respondents are correctly oriented in the forms. The respondents noted tests, counseling and training. 
Table 2 - Methods are most often used with learners with limited health opportunities (LHO)

\begin{tabular}{|c|c|c|c|c|c|}
\hline Category & № (\%) & Subcategory & № (\%) & Subcategory components & $\mathrm{N}(\%)$ \\
\hline \multirow{7}{*}{ Метод } & \multirow{7}{*}{$\begin{array}{c}46 \\
(54.1)\end{array}$} & method of psychotherapy & $3(3.5)$ & Art therapy & $3(3.5)$ \\
\hline & & Method of art therapy & $3(3.5)$ & Fairy tale therapy & $3(3.5)$ \\
\hline & & \multirow{4}{*}{ Methods of training and education } & \multirow{4}{*}{$33(38.85)$} & Conversation & $9(10.6)$ \\
\hline & & & & Game technology & $9(10.6)$ \\
\hline & & & & Exercises & $8(9.4)$ \\
\hline & & & & Brainstorm & $7(8,25)$ \\
\hline & & Methods of pedagogical research & $7(8,25)$ & Observation, questionnaires & $7(8,25)$ \\
\hline Type & $5(5.9)$ & Type of psychological assistance & $5(5.9)$ & Psychocorrection & $5(5.9)$ \\
\hline Direction & $2(2.4)$ & $\begin{array}{l}\text { The humanistic direction in } \\
\text { psychotherapy }\end{array}$ & $2(2.4)$ & Geshtalttherapy & $2(2.4)$ \\
\hline \multirow{5}{*}{ Form } & \multirow{3}{*}{$24(28,2)$} & $\begin{array}{l}\text { Form of measurement of learners' } \\
\text { knowledge quality }\end{array}$ & $8(9.4)$ & $\begin{array}{l}\text { Tests, including the test HTM (House, } \\
\text { Tree, Man) }\end{array}$ & $8(9.4)$ \\
\hline & & $\begin{array}{l}\text { Form of professional socio- } \\
\text { pedagogical activity }\end{array}$ & $3(3.5)$ & Consulting & $3(3.5)$ \\
\hline & & Form of active learning & $13(15.3)$ & Coaching & $13(15.3)$ \\
\hline & & & & No methods were used & $3(3.5)$ \\
\hline & & & & No answer & $5(5.9)$ \\
\hline
\end{tabular}

On the question of the methods that give the most tangible results in the correction of children with special educational needs (SEN) according to the observations of future social pedagogues, the students answered as follows: according to the results of the answers, 3 categories were defined: methods, forms and types. Methods have the highest rates $(47 \%)$. This category includes the following subcategories: method of rehabilitation by riding (hippotherapy), method (pedagogical system), methods of training and education, stimulating method, method of education, method of pedagogical research.

Currently, persons with limited health opportunities have the opportunity to receive vocational education for the purpose of further life self-realization and self-sufficiency. The task of the society in these conditions is to create a system of effective recreational services and physical rehabilitation in order to provide a favorable adaptive environment for social integration and inclusive education for persons with limited health opportunities. Hippotherapy, or therapeutic riding, today is one of the most effective methods of rehabilitation, adaptation and social integration of handicapped people. This method has been practiced all over the world for more than 50 years and is scientifically justified (Никитина, 2015).

Respondents pointed to the Montessori method, art therapy, game technologies, exercises.

The lesson of physical culture is the main form of systematic training of pupils to physical exercises. A special task of the lesson of physical culture is to teach children of all age groups the correct motor skills and the development of physical qualities. Inclusive education on the lessons of physical culture of the individual and inclusion of all in the learning process. So that children who have deviations for health reasons do not feel disconnected from society and, looking at healthy children, do not feel handicapped. The strategy in the classroom is that each teacher should analyze their practice, note the positive and negative aspects of their activities, constantly working with children from year to year, it is understood that something is missing to revive children, to give them an incentive (Белошицкая, 2019). 
The Readiness of Future Social Pedagogues to work in Inclusive Education: Results of a Diagnostic Research

Table 3 - According to the observations of future social pedagogues, methods, most often used and giving the most tangible results in the correction of learners with SEN

\begin{tabular}{|c|c|c|c|c|c|}
\hline Category & № (\%) & Subcategory & № $(\%)$ & Subcategory components & $\mathrm{N}(\%)$ \\
\hline \multirow{8}{*}{ Methods } & \multirow{8}{*}{$36(47)$} & $\begin{array}{c}\text { Method of rehabilitation by means of } \\
\text { hippotherapy }\end{array}$ & $3(4)$ & Hippotherapy & $3(4)$ \\
\hline & & Method(pedagogical system) & $2(2.7)$ & Method of Montessori & $2(2.7)$ \\
\hline & & Method of psychotherapy & $3(4)$ & Art therapy & $3(4)$ \\
\hline & & \multirow{2}{*}{ Methods of training and education } & \multirow{2}{*}{$13(17.3)$} & Game technologies & $6(8)$ \\
\hline & & & & Exercises & $7(9.3)$ \\
\hline & & Stimulating method & $3(4)$ & Encouragement & $3(4)$ \\
\hline & & method of education & $4(4.3)$ & Pattern of behaviour & $4(4.3)$ \\
\hline & & Method of pedagogical research & $8(10.7)$ & $\begin{array}{l}\text { Questionnaire, survey, } \\
\text { sociometry, diagnostics }\end{array}$ & $8(10.7)$ \\
\hline \multirow{6}{*}{ Формы } & \multirow{6}{*}{$19(25.3)$} & $\begin{array}{l}\text { Form of measurement of students' knowledge } \\
\text { qualities }\end{array}$ & $3(4)$ & Testing & $6(9)$ \\
\hline & & Form of studies & $1(1.3)$ & Physical education lesson & $1(1.3)$ \\
\hline & & \multirow{4}{*}{$\begin{array}{c}\text { Form of organization of classes, process of } \\
\text { learning and education }\end{array}$} & \multirow{4}{*}{$15(20)$} & Coaching & $3(4)$ \\
\hline & & & & Practical work & $1(1.3)$ \\
\hline & & & & Group work & $4(5.4)$ \\
\hline & & & & Individual work, consulting & $8(10.6)$ \\
\hline \multirow[t]{2}{*}{ Вид } & \multirow[t]{2}{*}{$8(10.7)$} & Type of pedagogical activity & $2(2.7)$ & $\begin{array}{l}\text { Socio-pedagogical, psycho- } \\
\text { pedagogical work }\end{array}$ & $2(2.7)$ \\
\hline & & Type of psychological assistance & $6(8)$ & Behavior correction & $6(8)$ \\
\hline & $8(10.7)$ & & & Not said, it is difficult to answer & $8(10.7)$ \\
\hline & & 75 semantic units we & defined & & \\
\hline
\end{tabular}

After analyzing the answers of future social pedagogues to the question what qualities should have a social pedagogue working with children with SEN, we identified 137 semantic units. The results are shown in table №4. The qualities that a social pedagogue working with children with SEN should possess are defined in 2 categories: personal qualities of a future social pedagogue $(76.1 \%)$ and professional qualities of a future social pedagogue $(23.9 \%)$. In the table it can be seen that the category as personal qualities of the future social pedagogue consists of 2 subcategories: personal qualities associated with human temperament (27.6 $\%$ ) and qualities formed in the process of socialization $(48.5 \%)$. It should be noted that the qualities formed in the process of socialization were a significant indicator. Among the personal qualities associated with human temperament, the highest index was noted in the component of the subcategory as kindness, love for children $(8.7 \%)$. Among the qualities formed in the process of socialization, responsibility has the highest index $(8.8 \%)$.

The category such as professional qualities of the future social pedagogue $(23,9 \%)$ is defined in 2 categories: academic and professional possession of the subject $(16,7 \%)$, and also the organization of work $(7,2 \%)$. In academic and professional possession of the subject, professionalism shows the highest rate. Thus, students are aware of the importance and necessity of professionalism as a professional quality of their future specialty. The German - British scientist, a psychologist, $H$. Eysenck gave great importance to the genetic factors which determine personality traits (Хьел, 2010).

The authors of this article in their previous works justify the importance of the development of competence of future social pedagogues as the most important criterion of professionalism of future pedagogues (Магауова, 2018). 
Table 4 - Qualities that should have a social pedagogue working with children with SEN (special educational needs)

\begin{tabular}{|c|c|c|c|c|c|}
\hline Category & № (\%) & Subcategory & № (\%) & Subcategory components & $\mathrm{N}(\%)$ \\
\hline \multirow{19}{*}{$\begin{array}{l}\text { Personal qualities of a } \\
\text { future social pedagogue }\end{array}$} & \multirow{19}{*}{$104(76.1)$} & \multirow{7}{*}{$\begin{array}{l}\text { Personal qualities associated } \\
\text { with human temperament }\end{array}$} & \multirow{7}{*}{$38(27.6)$} & Justice & $4(3)$ \\
\hline & & & & Observation & $1(0.7)$ \\
\hline & & & & Kindness, love for children & $12(8.7)$ \\
\hline & & & & Calmness & $11(8)$ \\
\hline & & & & Empathy & $8(5.8)$ \\
\hline & & & & Thoroughness & $1(0.7)$ \\
\hline & & & & $\underline{\text { Positiveness }}$ & $1(0.7)$ \\
\hline & & \multirow{12}{*}{$\begin{array}{l}\text { Qualities formed in the } \\
\text { process of socialization }\end{array}$} & \multirow{12}{*}{$66(48,5)$} & Communicability & $3(2.2)$ \\
\hline & & & & Education, culture & $3(2.2)$ \\
\hline & & & & Tolerance & $3(2.2)$ \\
\hline & & & & Humanity & $9(6.8)$ \\
\hline & & & & Responsibility & $12(8.8)$ \\
\hline & & & & Diversity & $3(2.2)$ \\
\hline & & & & Patience, endurance & $22(16)$ \\
\hline & & & & Strong character, confidence & $4(3)$ \\
\hline & & & & Punctuality & $2(1.5)$ \\
\hline & & & & Proper action & $1(0.7)$ \\
\hline & & & & Universal value & $1(0.7)$ \\
\hline & & & & Diligence & $3(2.2)$ \\
\hline \multirow{10}{*}{$\begin{array}{l}\text { Professional qualities of a } \\
\text { future social pedagogue }\end{array}$} & \multirow{10}{*}{$38(23,9)$} & \multirow{5}{*}{$\begin{array}{l}\text { Academic and professional } \\
\text { mastery of the subject }\end{array}$} & \multirow{5}{*}{$28(16,7)$} & Professionalism & $12(8.7)$ \\
\hline & & & & Awareness & $1(0.7)$ \\
\hline & & & & Competence & $2(1.5)$ \\
\hline & & & & Mastery & $7(5.1)$ \\
\hline & & & & Theoretical knowledge & $1(0.7)$ \\
\hline & & \multirow{5}{*}{ Labour organization } & \multirow{5}{*}{$10(7,2)$} & Organizational skills & $6(4.4)$ \\
\hline & & & & Knowledge of documentation & $1(0.7)$ \\
\hline & & & & $\begin{array}{l}\text { Correspondence to socio- } \\
\text { pedagogical requirements }\end{array}$ & $1(0.7)$ \\
\hline & & & & $\underline{\text { Systematicity }}$ & $1(0.7)$ \\
\hline & & & & Erudition & $1(0.7)$ \\
\hline
\end{tabular}

\section{Conclusions}

Thus, the implementation of inclusive education imposes special requirements to the social pedagogue, to his professional and personal development and involves the formation of personal qualities that should contribute to the development of professional competencies of the pedagogue of inclusive education. Based on the conducted research, we have identified a set of professionally 
significant qualities of a social pedagogue that are necessary for effective professional activity in conditions of inclusion: empathy, resistance to conflicts, stress resistance, tolerance, communication and organizational skills.

The study showed that the difficulties faced by future social pedagogues during pedagogical practice in working with a contingent of children with special educational needs can be distinguished"difficulties in relationships with persons with special educational needs."

Among the methods used to work with learners with SEN should be noted- " methods of training and education".

On the issue of methods that give the most tangible results in the correction of learners with special educational needs, according to the observations of future social pedagogues, the highest indicator was revealed - "methods" (methods of training and education).

Conducted survey showed that future social pedagogues are aware of traditional methods and technologies of inclusive education. But they do not have knowledge of modern strategies and models of inclusive education developed by foreign researchers.

Based on the results of the research, we offer the following recommendations:

1. In the context of implementing a competency-based approach to preparing social pedagogues to work in inclusive education, it is important not only to develop students' ability to use their theoretical knowledge in practice, but also to develop certain personal qualities and value orientations.

2. Psychological and pedagogical training of social pedagogues to work in an inclusive education should involve the formation of their professional competencies for the organization of joint training and interaction of children with normative development and children with SEN, as well as the ability to work in a team of specialists engaged in psychological, medical and pedagogical support of the educational process of persons with different educational needs.

3. It is necessary to strengthen the interdisciplinary training of social pedagogues, taking into account the fact that the conditions of inclusive education require knowledge in the field of pedagogy, psychology, medicine, physiology, sociology, etc.

4. Social pedagogues should not only be familiar with traditional socio-pedagogical technologies such as prevention, rehabilitation, correction, diagnostics, and counseling, but also be familiar with innovative strategies and models of inclusive education used in international practice.

Generally, during the analysis of the study, we were able to find out that students of the $3^{\text {rd }}-4^{\text {th }}$ year of bachelor's degree in "Social pedagogy and selfcognition" are predisposed to practical work in an inclusive education.

In this regard, there is a need to form their professional competencies that allow them to effectively carry out social and pedagogical activities to work with persons with special educational needs.

\section{References}

Mag A.G., Sandra Sinfield, \& Tom Burns (2017). The benefits of inclusive education: new challenges for university teachers, MATEC web of Conference 121, 12011

Beloshickaya Nataliya Aleksandrovna. Inkluzivnoye obrazovaniye i fizicheskaya kul'tura [Inclusive education and physical education]. sait uchitel'ya fizicheskoi kul'tury physical education teacher's website Social network of education workers nsportal.ru. URL:https://nsportal.ru/user/1096248/page/inklyuzivnoe-obrazovanie-i-fizicheskaya-kultura

Khamitova O.T. (2018). Effektivnyye empiricheskiye metody opytno-eksperimental'nogo issledovaniya v usloviyakh inkluzivnogo obrazovaniya. [Effective empirical methods of experimental research in inclusive education] Pedagogical science and practice 1(19). pp..70-72. (In Russian)

Kirillova. E., Nabiullina R., Faizrakhmanova A. (2016). Teachers' Preparadness for Activity in the Context of Inclusive Practice. Proceeding of the $1^{\text {st }}$ World disability and Rehabilitation Conference, Vol.1, pp. 14-21.

L. Hjell, D. Ziegler. (2010). Theories of personality. - $3^{\text {rd }}$ edition. - Spb., 607 p. (In Russian)

Lakhin R.A. (2016). Social'no-pedagogicheskii potencial narodnoi igry v inklusivnom obrazovanii. Istoricheskaya I social'no obrazovatel'naya mysl'. [Social and pedagogical potential of the folk game in inclusive education. Historical and socio-educational thought.]. Volume 8. №5. Part 3. pp. 96-100. (In Russian)

Magauova A.S., Makhambetova Zh.T. (2018). Osnovnyye tendencii inkl'uzivnogo obrazovaniya v Respublike Kazakhstan. [The main trends of inclusive education in the Republic of Kazakhstan]. Sayasat-Policy. pp. 4-9 (In Russian)

Marshall, G.B., \& Rossman, C. (2011). Designing qualitative research. London: Sage.

Nikitina N.A. (2015). Ippoterapiya, ili lechebnaya verkhovaya yezda, kak metod fizicheskoi reabilitacii I adaptacii invalidov pri inkluzivnom obrazovanii. [Hippotherapy, or therapeutic horse riding, as a method of physical rehabilitation and 
adaptation of disabled people in inclusive education.]. Bulletin USPTU. Science, education, economy. Series economy. pp. 51-53. (In Russian)

Ossipova A. A. Obshaya psikhokorrekciya// General psycho-correction : textbook for university students - M.: TS Sfera, 2004. (In Russian)

Petrie, P., Boddy, J., Cameron, C., Wigfall, V. and Simon, A. (2006) Working with Children in Care:European Perspectives. Buckingham: Open University Press.

T.Yu. Koloshina, A.A.Trus' (2010). Art-terapevticheskiye techniki v treninge: kharakteristiki I ispolzovaniye. [Art-therapeutical techniques in coaching: characteristics and usage]. SPb.-Rech'. 16 p. (In Russian)

Zhumasheva S.A., Panikarskaya M.A., Alkhatova T.S., Rakisheva A.Zh. (2017). Primeneniye igrovoi formy tekhnologii na zanyatiyakh v nachal'nykh klassakh innovcionno-inkluzivnogo obrazovaniya. [Application of the game form of technology in the classroom in the primary classes of innovative - inclusive education]// Problems of pedagogy. №3 (26). URL: https://cyberleninka.ru/ article/n/primenenie-igrovoy-formy-tehnologii-na-zanyatiyah-v-nachalnyh-klassah-inovatsionno-inklyuzivnogo-obrazovaniya (date of reference: 06.05.2019). (In Russian)

\section{Литература}

1. Mag A.G., Sandra Sinfield, \& Tom Burns (2017). The benefits of inclusive education: new challenges for university teachers, MATEC web of Conference 121, 12011

2. Petrie, P., Boddy, J., Cameron, C., Wigfall, V. and Simon, A. (2006) Working with Children in Care: European Perspectives. Buckingham: Open University Press.

3. Marshall, G.B., \& Rossman, C. (2011). Designing qualitative research. London: Sage.

4. Kirillova. E., Nabiullina R., and Faizrakhmanova A. (2016). Teachers' Preparadness for Activity in the Context of Inclusive Practice. Proceeding of the $1^{\text {st }}$ World disability and Rehabilitation Conference, Vol.1, pp. 14-21.

5. Осипова А. А. Общая психокоррекция: учебн. пос. для студ. вузов. - М.: ТЦ Сфера, 2004.

6. Колошина Т.Ю., Трусь А.А. (2010). Арт-терапевтические техники в тренинге: характеристики и использование: Практическое пособие для тренера. - СПб.: Речь. - С.16.

7. Хамитова О.Т. (2018). Эффективные эмпирические методы опытно-экспериментального исследования в условиях инклюзивного образования // Педагогическая наука и практика 1 (19). С. 70-72.

8. Жумашева С. А., Паникарская М. А., Алхатова Т. С., Ракишева А. Ж. Применение игровой формы технологии на занятиях в начальных классах инновационно-инклюзивного образования // Проблемы педагогики. 2017. №3 (26). URL: https://cyberleninka.ru/article/n/primenenie-igrovoy-formy-tehnologii-na-zanyatiyah-v-nachalnyh-klassah-inovatsionno-inklyuzivnogo-obrazovaniya (дата обращения: 06.05.2019).

9. Лахин Р.А. Социально-педагогический потенциал народной игры в инклюзивном образовании // Историческая и социально-образовательная мысль. 2016. Том 8. № 5. Часть 3. С. 96-100).

10. Никитина Н.А. (2015). Иппотерапия, или лечебная верховая езда, как метод физической реабилитации и адаптации инвалидов при инклюзивном образовании // Вестник УГНТУ. Наука, образование, экономика. Серия: Экономика. - С. 51-53.

11. Белошицкая Н.А. Инклюзивное образование и физическая культура // сайт учителя физической культуры Социальная сеть работников образования nsportal.ru. URL:https://nsportal.ru/user/1096248/page/inklyuzivnoe-obrazovanie-i-fizicheskayakultura

12. Хьелл Л., Зиглер Д. (2010). Теории личности. - 3-е изд. - СПб.: Питер, 2010. - 607 с.

13. Магауова А.С., Махамбетова Ж.Т. Основные тенденции инклюзивного образования в Республике Казахстан // Саясат-Policy. №9/2018. - C. 4-9. 